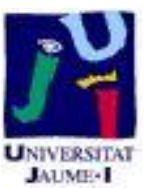

Título artículo / Títol article:

The price of modern maritime piracy

Autores / Autors

Inmaculada Martínez Zarzoso ; Sami Bensassi

Revista:

Defence and Peace Economics, 2013, vol. 24, núm. 5

Versión / Versió:

Pre-print

Cita bibliográfica / Cita

MARÍNEZ ZARZOSO, Inmaculada ; BENSASSI Sami. bibliogràfica (ISO 690): Defence and Peace Economics, 2013, vol. 24, núm. 5, p. 397-418

url Repositori UJI:

http://hdl.handle.net/10234/94150 


\title{
The price of modern maritime piracy
}

Defence and Peace Economics 24 (5), 397-418. October 2013.

\author{
Inmaculada Martínez-Zarzoso*, Sami Bensassi**,
}

\begin{abstract}
A growing body of literature has recently focused on the economic origins and consequences of modern maritime piracy and on the perception that the international community has failed to control it. This paper aims to investigate maritime transport costs as one of the channels through which modern maritime piracy could have a major impact on the global economy. A transportcost equation is estimated using a newly released dataset on maritime transport costs from the OECD together with data on maritime piracy from the IMB. Our results show that maritime piracy significantly increases trade costs between Europe and Asia.
\end{abstract}

Key words: maritime piracy, transport costs, maritime trade, panel data

JEL Classification: F51

* Department of Economics, University of Goettingen, Germany. Phone: 0049-551-39 7350, Fax: 0049551-39 7279. Email: martinei@eco.uji.es. Department of Economics and Institute of International Economics, Universitat Jaume I, Spain. Financial support from the Spanish Ministry of Science and Technology is gratefully acknowledged (ECO 2010-15863).

** Department of Economics, Universitat Jaume I, Campus del Riu Sec, 12071, Castellón, Spain. Phone: 0034-964-72 85 90, Fax: 0034-964-72 85 91. Email: bensassi@eco.uji.es. 


\section{1- Introduction}

There is growing evidence showing that maritime piracy increases maritime transport costs for a number of reasons. First, in 2008 some ship-owners have made clear their intention to re-route some of their lines to avoid dangerous waters. Second, Lloyds added the Gulf of Aden to its list of warzones in May 2008, based on the claim of insurers and sailors for a premium when a vessel navigates in this region. Finally, firms providing security services are flourishing as a consequence of piracy ${ }^{1}$. Those are probably the main channels through which freight rates are impacted by maritime piracy. However, the lack of systematic data on insurance contracts ${ }^{2}$, salaries paid by ship-owners, the proportion of ships re-routed, the investment in defense measures and poor data on freight rates makes it difficult to conduct a comprehensive study of the impact of piracy on transport costs. This is an important caveat given that in a world of decreasing trade barriers (custom duties and tariffs), transport costs have become one of the main obstacles to international trade (Hummels, 2001).

As acts of piracy mainly occur on the Euro-Asia maritime trade route, higher freight rates may hinder trade between these two continents. Increasing transport prices might also reinforce the idea put forward by the shipping industry to develop a northern trade route between Europe and

\footnotetext{
${ }^{1}$ The most important shipping companies, CMA-CGM, MSC and Maersk have announced in 2009 they would divert some of their lines through the Cape route (Times 2008, Port Strategy 2009). The Indian shipping association has declared that depending on the size, the war risk premium for merchant vessels sailing in the Indian Ocean has risen from $\$ 500$ per ship and per voyage to as much as $\$ 150,000$ per ship and per voyage (Financial Express, 2011). Shipping companies such as Interoient Line Services have considered hiring private security service companies, costing US $\$ 60,000$ per trip (Miller, 2008).

${ }^{2}$ See Ploch et al. (2010) for more information on the problems linked to insurance, notably the fact that US shipowners do not have to insure themselves against the risk of war.
} 
Asia, passing through the Arctic region. This development could have far-reaching consequences in terms of environmental costs and on the economies currently benefiting from their position on the current route between Europe and Asia, such as Egypt or Singapore.

This paper aims to fulfill some of the abovementioned gaps in the literature by testing the effect of modern maritime piracy on maritime trade costs. We propose a simple model of transport cost determination and derive a transport costs equation augmented with maritime piracy as an additional explanatory variable. As far as the authors of this paper are aware, this is the first study that focuses on unitary transport costs as a response variable. We overcome the major hurdle of data availability by using a new database on maritime transport costs compiled by the Organization for Economic Cooperation and Development (OECD) and data on modern maritime piracy obtained from the International Maritime Bureau (IMB). The information at industry level provided in the maritime transport cost database allows us to test whether pirates attack more ships transporting certain types of goods ${ }^{3}$.

Our findings reveal that maritime piracy has a significant and positive impact on maritime transport costs. One additional ship hijacked results in a $1.2 \%$ increase in maritime transport costs between Europe and Asia. These results may be important for policymakers interested in the relative position of Euro-Asian trade compared to USA-Asian trade. In particular, we show that localized conflicts could selectively harm some international trade routes.

This paper is organized as follows: Section 2 reviews the literature on maritime piracy and transport costs. Section 3 describes the data and presents some descriptive statistics. Section 4

\footnotetext{
${ }^{3}$ Hastings (2009) reports anecdotal evidence suggesting that may be the case in the Malacca Strait.
} 
outlines the specification of the model and empirical estimation and section 5 presents the main results. Concluding remarks are presented in section 6 .

\section{2- MARITIME PIRACY AND TRANSPORT COSTS}

Our paper brings together two different strands of the economic literature: while the first analyzes the economic aspects of modern maritime piracy, the second focuses on the determinants of international transport cost.

\subsection{Modern maritime piracy and international trade}

A number of international trade economists have modeled the impact of adverse conditions, such as insecurity, conflicts and terrorism, on international trade (Anderson and Marcouiller, 2002 and 2005; Mirza and Verdier, 2008). Maritime piracy has also been specifically linked to trade. In particular, Bendall (2010) and Fu et al (2010) focus on the economic impact of maritime piracy on trade through the decision of ship operators to change their main trade routes between Europe and Asia in order to avoid Somali piracy. Moreover, Bensassi and Martinez-Zarzoso (2011) evaluate the impact of maritime piracy on the volume of trade between European and Asian countries. We aim to extend this research by analyzing the effect of maritime piracy on the price of maritime transport.

We also contribute to the ongoing debate in the scientific community on the motivations and methods used by pirates. Some researchers sustain that pirates do not choose their prey according to the shipment transported by the vessel (Mejia and al, 2009), but tend to avoid attacking ships flying the colors of countries with a military presence in the immediate vicinity (Kiourktsoglou and Coutroubis, 2010). Another view supported by Hastings (2009) is that pirates choose their 
targets according to the value of the shipment transported on the black market. This author indicates that Somali and Malaccan pirates behave differently. While Somali pirates are mostly interested in the ransom they expect to receive for the ship and the crew, Malaccan pirates are mostly interested in rapidly selling back their loot. The main reason for this behavior is the pressure exerted by the authorities around them and the possibility that a particular region will offer to sell back the stolen freight. However, the fact that Malaccan pirates care about the shipments of the vessels they attack does not mean that they will systematically prey on the same sort of merchandise. Our paper gives some support to the first argument, that is, pirates are not concerned with the type of good transported, by showing that this is not the case at least within broadly defined goods categories.

\subsection{The determinants of transport costs}

International trade economists have been using the iceberg transport $\operatorname{cost}^{4}$ formulation for many years as an analytical device that greatly simplifies trade analysis. However, the explicit iceberg assumption is not observational or empirical. Indeed, transport costs per ton are not invariant with respect to the tonnage of the material delivered. In applied work, distance has been used for many years in gravity models of trade as a proxy for transport costs, assuming that transport costs are an increasing function of distance between the trading countries. However distance remains an unsatisfactory measure of trade costs because it is time-invariant and independent of the tonnage of transported goods. It has been only in the last two decades that more sophisticated methods have been employed to measure transport costs and to analyze their impact on international trade. In the early 2000s, Limao and Venables (2001) and Micco and Perez (2001)

\footnotetext{
${ }^{4}$ According to the iceberg transport cost assumption, some of the goods to be delivered are consumed by the very act of transporting.
} 
added infrastructure variables to gravity equations to better characterize the impact of transport costs on trade. A second wave of research emphasized that transport costs are indeed endogenously determined (Martinez Zarzoso and Suarez Burguet, 2005; Wilmsmeier and Martinez-Zarzoso, 2010; Korinek and Sourdin, 2009a,b). Transport costs may be endogenous for a number of reasons, such as the presence of economies of scale in transport or the existence of trade imbalances that cause the price of transport to differ depending on the direction of trade. For example, Martinez Zarzoso and Suarez Burguet (2005) estimate a simultaneous system of equations of transport costs and trade where both variables are considered endogenous. Similarly, Wilmsmeier and Martinez-Zarzoso (2010) propose a transport costs model in which trade is endogenous and trade imbalances are an important determinant of transport costs. We specify a similar model introducing modern maritime piracy as an additional variable that determines international maritime transport costs.

Finally, it is worth mentioning that exploring the channels through which piracy affects transport costs using statistical methods is beyond the scope of this paper. As mentioned in the introduction, we only found anecdotal evidence showing that sailors' salaries and insurance cost had increased as a consequence of maritime piracy. Indeed, we did not find comprehensive data on either insurance premiums or sailors' salaries. In addition, differences between the various types of insurance across countries made any type of comparison difficult. For example, the U.S Maritime War Risk Insurance Program covers the additional risk of maritime piracy directed against U.S vessels (Ploch et al. 2010).

Concerning the use of the Cape Route, it is particularly difficult to make a clear evaluation of the number of ships that are being effectively re-routed. It is hard to believe that re-routing ships around the Cape is a safe solution for most of the maritime commercial traffic, as the activities of 
Somali pirates has spread to the north of Madagascar and Mauritius (see Figure 1). Finally, shipping companies are particularly secretive when it comes to the measures they take to defend their ships. We fail to find satisfying proxies for either of these variables to be used in our study.

\section{MARITIME PIRACY AND TRANSPORT COSTS: THE CURRENT SITUATION}

\subsection{Geography of maritime trade and piracy}

Maritime piracy depends on the existence of advantageous geographical conditions, namely narrow straits to spot future preys, islets or coastal areas remote enough to escape any form of authority (Murphy, 2008; Ong-Webb, 2007). Not only geographical conditions are important, but also the geo-economic and political context of the countries suitably located to host piracy. Maritime piracy could indeed take roots when intensively used maritime trade routes pass nearby potential pirates' harbors located in failed or weak states. Nowadays, the two main maritime piracy hot spots, the Malacca straits and the Gulf of Aden, both have these favorable conditions. Malaccan piracy was more intense in the late nineties, whereas Somali piracy plays the leading role today. These two hot spots of maritime piracy are located on the trade routes linking Asia to Europe.

In order to examine the extent of the problem posed by piracy to shipping between Europe and Asia, we rely on a similar strategy to that in Bensassi and Martinez-Zarzoso (2011), but focus on the price of transport as the response variable instead of focusing on trade volumes. We have divided the oceans between the two continents into five regions: the European Seas (ES) from the coastal areas of Iceland and Norway in the North to the waters of the Canary Islands in the South, in addition to the Mediterranean and Black Seas; the Red Sea and the Gulf of Aden 
(RSGA) which includes a vast area of the Indian Ocean along the shores of Oman, Somalia and Tanzania; the Indian Sub-Continental Seas (ISCS) along the shores of Pakistan, India, Bangladesh, Sri Lanka and the Maldives; the South-East-Asian Seas (SEAS) comprising the waters of Indonesia and the Philippines, as well as those of Malaysia, Vietnam, Thailand, Burma and Cambodia; and the East-Asian Seas (EAS) which encompasses the Yellow Sea between China and Korea, the East and South China Seas and the Japanese coasts .

\section{Figure 1. Maritime Regions}

A ship heading from a port in northern Europe to China must cross all five maritime regions; four if it ends its journey in Singapore and three if it unloads its shipment in Mumbai (see Table A.1 in the Appendix). The International Maritime Bureau (IMB) Live Piracy Report offers information on the number of annual incidents of piracy in each of the five regions between 1999 and 2007, as well as the number of incidents on three different routes linking Europe and Asia over this 9-year period (see Graph A.1 \& A2 in the Appendix).

We are mostly interested in the Euro-Asia route because very few piracy incidents occur on the main shipping lines connecting other large economic areas. One way to investigate the impact of piracy on transport costs geographically is to compare the evolution of transport costs on the Europe-Asia route with trends in other regions that are not affected by piracy. Figure 2 shows the trend in maritime transport costs on two trade routes: the USA-EU15 trade route and the ChinaEU15 trade route. Only the second route has been plagued with a high level of piracy. The graph shows that the freight rates for container transport have behaved differently on each trade route. While transport costs are clearly decreasing in USA-EU15 trade, numbers are only slightly decreasing for the China-EU15 over the entire period, with spikes in 1999 and 2004. These peaks 
could be due to maritime piracy, but market conditions may also have played an important role. This paper shows that piracy has a "positive" impact on maritime trade costs once the impact of the size of the trading countries, the trade imbalance between these countries, their volume of trade and other unobservable time-variant factors common to all routes are taken into account.

\section{Figure 2. Average transport freight rates for two alternative routes}

We differentiate between three kinds of incidents according to the extent to which a ship's journey is disrupted: attempted acts of piracy, boarding acts and hijackings. An attempted act of piracy occurs when pirates board a ship and abandon it empty-handed after being discovered, or when a ship comes under fire without being stopped. Instances of boarding entail the actual boarding of a ship by pirates and theft (generally the personal belongings of the crew and/or goods carried for crew maintenance and en-route ship repairs). These incidents may involve violence against the crew. The last type of piracy, hijacking, consists in the seizure of the ship and its crew, the immobilization of the ship in a coastal area under the control of the pirates and a ransom being demanded in exchange for the crew members, the ship and its cargo. Hijackings are obviously the most disruptive for maritime trade. Figure 3 shows the evolution over time of the three types of acts of piracy between Europe and East Asia.

Figure 3. Number of piracy acts by type on the Europe-East Asia Route

\subsection{MEASUREMENT OF TRANSPORT COSTS}

One of the main difficulties in analyzing transport costs is obtaining reliable data. There have been several attempts in the recent economic literature to measure transport costs either directly or indirectly. Some authors have used $\mathrm{CIF} / \mathrm{FOB}$ ratios as a proxy for shipping costs (Baier and Bergstrand, 2001, Limao and Venables, 2001; Radelet and Sachs, 1998). Since most importing 
countries report trade flows inclusive of freight and insurance (CIF) and exporting countries report trade flows exclusive of freight and insurance (FOB), transport costs can be calculated as the difference between both flows for the same aggregate trade. However, Hummels (1999b) showed that importer $\mathrm{CIF} / \mathrm{FOB}$ ratios constructed from IMF sources are poor proxies for crosssectional variation in transport costs and such variables provide no information about changes in transport costs over time. Oguledo and Mcphee (1994) also doubted the usefulness of CIF/FOB ratios from IMF sources as a proxy of transportation costs.

Several authors have attempted to construct more accurate measures of transport costs. Hummels (1999a, 1999b) use data on transport costs from various primary sources including shipping price indices obtained from shipping trade journals (Appendix 2 in Hummels, 1999b) and freight rates (freight expenditures on imports) collected by customs agencies in the United States, New Zealand and five Latin American countries (Mercosur plus Chile). In addition to the CIF/FOB ratios reported by the IMF, Limao and Venables (2001) use shipping company quotes for the cost of transporting a standard container (40 feet) from Baltimore to sixty-four destinations. The authors pointed out that it is not clear how the experience of Baltimore can be generalized. Martínez-Zarzoso et al. (2003) use data on transportation costs obtained from interviews with shippers in Spain. Micco and Perez (2001) use data from the U.S Import Waterborne Databank (U.S. Department of Transportation), where transport costs are defined as "the aggregate cost of all freight, insurance and other charges (excluding U.S. import duties) incurred in bringing the merchandise from the port of exportation to the first port of entry in the U.S.". Sanchez, Hoffmann, Micco, Pizzolitto and Sgut (2002) analyzed data on maritime transport costs obtained from the International Transport Data Base (BTI). They focused on Latin American trade with NAFTA. 
In this paper, we use a newly released database from the OECD, which overcomes some of the problems presented by the precedent databases. This database contains maritime trade for 20 importing countries and 218 exporting countries for the period 1991 to 2007, covering different categories of products. The data come from several reliable sources (original customs data from Australia, New Zealand and the United States and also private sources, such as Containerization International, Drewry Consulting and the Baltic Dry Shipping Index). A sound methodology is used to harmonize these various sets of observations (Korinek, 2008). The advantages of this database in terms of comprehensiveness and time span make it a valuable tool for the study of transport costs (Korinek and Sourdin, 2009a,b). Figure 4 displays the evolution of average unit transport costs for four categories of goods (manufactured goods, dirty bulk, crude oil and agricultural goods) exported from Europe (EU15) to Asia.

Figure 4. Average maritime transport costs for four types of goods shipped between Europe and Asia

\section{FACTORS EXPLAINING TRANSPORT COSTS}

\subsection{Model specification}

A general formulation of transport costs for commodity $k$ shipped between countries $i$ and $j$, in a given period of time, can be written as:

$$
T C_{i j k t}=F\left(X_{i t}, X_{j t}, v_{i j t}, \omega_{k}, \mu_{i j}, \varphi_{t}\right)
$$

where $X_{i t}$ and $X_{j t}$ are country-specific characteristics, $v_{i j t}$ is a vector of characteristics related to the journey between $i$ and $j, \omega_{k}$ is a product-specific effect that captures differences in transport 
demand elasticity across goods, $\mu_{\mathrm{ij}}$ represents unobservable heterogeneity that is specific to each trade flow and $\varphi_{t}$ denotes time-specific unobservable heterogeneity.

GDP and the population of the trading countries are used to proxy for country-specific characteristics, such as infrastructure and the quality of institutions ${ }^{5}$. The vector $v_{i j \mathrm{t}}$ includes the trade imbalance between countries $i$ and $j$, a proxy for economies of scale is the volume traded between countries $i$ and $j$, and our variable of interest, namely the number of piracy incidents involving hijacking along the trade route linking country $i$ and $j$. Distance between $i$ and $j$ and other variables related to each bilateral trade relationship could be added to model $\mu_{\mathrm{ij}}$, but we have preferred to specify bilateral fixed effects $\mu_{i j}$ in order to capture all the time-invariant unobserved heterogeneity attached to each pair of trading countries. Product-specific dummy variables are used to account for $\omega_{k}$ and time-specific dummy variables $\left(\varphi_{t}\right)$ are added as a proxy for unobserved variables that influence transport costs and are time-variant but common to all trading pairs, such as technological improvements in transport.

Assuming a multiplicative form, a transport cost function is specified as:

$$
T C_{i j k t}=Y_{i t}^{\alpha_{1}} Y_{j t}^{\alpha_{2}} \operatorname{Pop}_{i t}^{\alpha_{3}} \operatorname{Pop}_{j \mathrm{t}}^{\alpha_{4}} \operatorname{Im} b_{i j \mathrm{t}}^{\alpha_{5}} X M_{i j t}^{\alpha_{6}} e^{\beta_{1} h i j a c k_{r_{i} t}+\mu_{i j}+\omega_{k}+\varphi_{t}+\varepsilon_{i \mathrm{k} \mathrm{kt}}}
$$

where $T C_{i j k t}$ denotes unitary maritime transport costs for each 2-digit HS product category, $i$ denotes the importer country, $j$ the exporter country, $t$ the year and $k$ the 2-digit level of the HS classification. $Y$ represents the GPD of the corresponding country, while Pop denotes population. Imb is the trade imbalance between country $i$ and $j$ calculated as the difference between exports from $i$ to $j$ and imports of $i$ from $j$ in absolute value. $X M$ denotes trade volumes in tons calculated

\footnotetext{
${ }^{5}$ We also used alternative variables, namely road infrastructure and a linear shipping connectivity index as proxies for infrastructure. The results concerning our target variable remained unchanged and are available upon request from the authors.
} 
as the sum of exports and imports, Hijack $k_{r t}$ is the number of piracy incidents involving hijacking along the trade route $r$ in year $t$ linking country $i$ and $j$. Other types of piracy incidents (boarded ships and attempted attacks) will also be considered as explanatory variables. $\mu_{i j}$, $\omega_{k}$ and $\varphi_{t}$ denote the different sets of fixed effects described above. Finally, $\varepsilon_{i j k t}$ is the error term that is assumed to be identically and independently distributed.

Taking natural logarithms of equation (2) we obtain a linear version of the general specification given by,

$$
\begin{gathered}
\ln T C_{i j t}=\alpha_{1} \ln Y_{i t}+\alpha_{2} \ln Y_{j t}+\alpha_{3} \ln \text { Pop }_{i t}+\alpha_{4} \ln P o p_{j t}+\alpha_{5} \ln I m b_{i j t}+\alpha_{6} \ln X M_{i j t} \\
+\beta_{1} h i j a c k_{r, t}+\mu_{i j}+\omega_{k}+\varphi_{t}+\varepsilon_{\mathrm{ijjkt}}
\end{gathered}
$$

where ln denotes natural logarithms and all the variables have been described after equation (2).

\subsection{Data and variables}

In this section we describe the data and variables used in our empirical work. Sources and variable definitions are listed in Table A.2. The dependent variable (TC) is obtained from the OECD data base on maritime transport costs. We use the maritime transport costs between the European Union and 13 destinations in Asia $^{6}$ for each HS 2 digits class of goods. We differentiate four types of goods: manufactured goods, raw materials, agricultural goods and crude oil. The target variable is $t \_h i j a c k$, which stands for the number of hijacked ships on a particular route. Each pair of countries is associated with one trade route. We expect $t$ h hijack to correlate positively with maritime transport costs. Other variables that measure piracy incidents

\footnotetext{
${ }^{6}$ For the European Union, the maritime transport cost database considers the EU15 as a single emitter of data. Data for Bulgaria, Cyprus, the Czech Republic, Estonia, Hungary, Latvia, Lithuania, Malta, Poland and Slovenia are also available. The Asian countries in our dataset are Bangladesh, China, Indonesia, India, Japan, South Korea, Malaysia, The Philippines, Singapore, Thailand and Vietnam. Australia was added to this group.
} 
are: $t$ boarded, the number of incidents in which a ship has been boarded but not hijacked; and t_attempted, the number of attempted attacks that do not succeed. These two variables will also be used in the empirical analysis as additional explanatory variables.

Additional explanatory variables are: $\operatorname{GDP}\left(Y_{i t} ; Y_{j t}\right)$, population $\left(P_{o p_{i t}} ; \operatorname{Pop}_{j t}\right)$, trade imbalances $\left(I m b_{i j t}\right)$ and trade volumes $\left(X M_{i j t}\right)$. The source for the three first variables is the world development indicators dataset (WDI) from the World Bank. GDP and the population of the importer and exporter countries are used as control variables for country characteristics. Trade imbalance is expected to be negatively correlated with bilateral maritime transport costs if bidirectional transport costs between two regions are jointly determined, since transport costs will depend on the relative demand for transport between regions (Jonkeren, Demirel Ommeren and Rietveld, 2010). Finally trade volume is expected to have a reducing effect on transport prices, since routes characterized by intense trade may foster competition and reduce transportation costs. This variable has been obtained from Eurostat. Summary statistics of the described variables are presented in Table 1.

\section{Table 1. Summary statistics}

An alternative variable that could be used instead of piracy events is the Lloyd's classification of a warzone. Table A.3 shows the evolution of the different zones monitored in the last 6 reports of the Joint War Committee available on line. We would like to underline that for most of the observations, when a country is listed the war zone refers to the limits of the national waters of this country. This definition, pertinent and useful when a war has occurred and insurance companies require a strictly defined geographical perimeter, is in our opinion limited when it comes to addressing the problem of piracy. With the only exception of thieves in ports, pirate 
attacks occur en route. It is true that most of these attacks take place not far from a coastal area, but pirates do not feel bound by the territorial limits defined internationally (particularly in the zones were several national maritime zones are in contact or very close, as in the Gulf of Aden or the Strait of Malacca). The joint war committee has tackled this problem by defining broader zones of danger (Gulf of Aden, Sulu Archipelago). In this instance, the Gulf of Aden zone juxtaposes almost perfectly with the Red Sea Gulf of Aden maritime zone defined in our paper. Even if similar zones are defined, the war zone classification has the important disadvantage of not revealing any information on the intensity of the conflict and also displays very few variations over time. By providing a count of the number of incidents over time for each geographic zone and trade route defined, the IMB database was more suitable for the type of study we aimed to carry out. Despite the abovementioned disadvantages we decided to use also warzones in addition to piracy events in the robustness checks' section.

\section{Empirical application and main results}

\subsection{Main results}

Equation (3) has been estimated using a least squares dummy variable estimator (LSDV) with different sets of dummies to control for unobservable heterogeneity. To test whether piracy acts have different impacts on transport costs depending on the nature of transported goods, we estimate Equation (3) for four different types of goods (agriculture, manufactures, raw materials and crude oil) and two different types of transport (container carriers and tankers transporting dirty bulk). Two types of piracy acts, namely the number of hijacked ships and number of boarded ships, enter the trade cost equation significantly ${ }^{7}$. In addition, aggregate attacks and also

\footnotetext{
${ }^{7}$ Attempted attacks were also originally considered, but the variable was not statistically significant and as a result is not included in the final estimations.
} 
pirate success rates calculated as (hijacks/aggregate attacks) are also considered as target variables. The baseline estimation results are shown in Table 2 (LSDV estimates). The estimated effect of piracy on transport costs is slightly lower when aggregate effects are considered in comparison with the single coefficients for hijacks and boarded ships (column 1 in Table 2). Column 6 in Table 2 shows the results for aggregate attacks (t_tot). As regards the results concerning success rates (column 7 in Table 2), the estimated coefficient for aggregate trade is 2 , indicating that an increase of 1 percent in the rate of success increases transport costs by 2 percentage points ${ }^{8}$.

\section{[Table 2]}

In Table 3 we estimate Equation (3) with the variables $t \_$hijack and $t$ _boarded lagged two years ${ }^{9}$. In doing so, we control for the possibility that shipping contracts are agreed upon in advance. The estimated coefficients for the different sets of fixed effects $(k, i j, t)$ are not shown ${ }^{10}$. Both Tables report the results assuming common coefficients for all types of products in the first column and specific estimates for four different types of goods, namely manufactures, agricultural goods, raw materials and crude oil in columns 2, 3, 4 and 5, respectively.

\section{[Table 3]}

In both estimations (LSDV and LSDV with lagged piracy variables) the piracy coefficients have the expected positive signs and are statistically significant at conventional levels for total trade, manufactures and agricultural products. The coefficients in Table 3 are slightly higher for

\footnotetext{
${ }^{8}$ Similar results were obtained when the variables were lagged one and two years concerning the coefficients of aggregate attacks and success rates. These results are available upon request from the authors.

${ }^{9}$ We would like to thank an anonymous referee for this suggestion. Similar results obtained with the variable lagged one period are available upon request.

${ }^{10}$ These results are available upon request from the authors.
} 
t_hijack when total trade, manufactures and agricultural products are considered and are also positive and significant for raw materials and crude oil. One additional hijacked ship results in an increase of around 1.6 percent in maritime transport costs (Table 3, column 1) between Europe and Asia. A positive and significant effect is also found for manufactures and agricultural goods considered separately in both specifications and for raw materials and crude oil only using lagged values of piracy incidents. One additional act of hijacking results in an increase of around 1.5 percent and 1.4 percent in maritime transport costs for manufactured goods and agricultural goods respectively. When considering boarded ships as piracy acts, the impact on transport costs is lower, but also positive and statistically significant for all categories of goods in Table 2 and for the two main categories (agricultural and manufactured products) in Table 3.

According to our data, the unit maritime transport cost of footwear was US\$0.505 in 2007, which for a shipment of 10,000 units of footwear between Europe and Asia amounts to US\$5,050. One more act of hijacking results in an increase of US\$75.75 for the shipment. Furthermore, if we also consider the number of piracy acts resulting in the successful boarding of a ship, transport costs would increase by US\$96. The coefficient on the variable $t$ _boarded is not statistically significant for raw materials or for crude oil when lagged values are used (Table 3, columns 4 and 5). However for these two categories of goods the number of observations available is very low in comparison with manufactures and agricultural products. This is probably the reason why the results are less robust to changes in the specification.

\subsection{Robustness checks}

We mentioned that there is some controversy in the scientific community concerning the fact that pirates may choose the ships they attack according to the good transported. Since transport costs 
depend on the nature of the goods transported, the piracy variable in Equation (3) might be endogenous. As a first robustness check, we estimate Equation (3) for ships transporting containers on the one hand and for tankers and ships transporting dirty bulk on the other. Tankers are one of the main categories of ships under attack according to the ICC database (see Table A.4). However, it seems that very few attacks on this kind of vessel are successful and result in hijacking. Among the 30 attacks on oil tankers in 2008 , only one was successful ${ }^{11}$. Among the observations in our dataset, crude oil is transported by tanker, but also by dirty bulk ships. Therefore, we have aggregated these two categories. The results are shown in Table 4 and indicate that the impact of piracy is greater for tankers and ships transporting dirty bulk.

\section{[Table 4]}

As a second robustness check, we instrument the number of vessels hijacked with the number of hijacks in the three previous years (the same was done for number of boarding acts). The model is estimated using a Generalized Method of Moments (GMM) that is robust to heteroskedasticity and autocorrelation of unknown form. We also employed past boarding attempts as instruments, but the variables are correlated with the number of vessels hijacked and are not independent of the type of transported goods, therefore being correlated with the error term in our transport cost equation.

The results of the GMM estimation are reported in Table 5 for all goods (column 1), for manufactures (column 2) and for agriculture (column 3). We were unable to find valid instruments for crude oil and raw materials. Our variable of interest stays positive and significant and the magnitude is similar to that obtained in Table 3. It is worth noting that although widely

\footnotetext{
${ }^{11}$ The successful attack on the Sirius Star, a new launch Saudi Arabian super tanker, made headlines for several weeks in 2008. It is still the largest ship captured by Somali pirates to date.
} 
used in the empirical literature, the use of internal instruments may not be the best strategy. We leave this issue for further research.

\section{[Table 5]}

As a third robustness check, ${ }^{12}$ we use warzone data for the period 2000-2010 and create a new variable indicating the number of warzones per trade route and year. Unfortunately, the methodology to classify war areas changed after 2004, creating an artificially large difference between the period 2000-2004 and 2005-2011 (See Figure A.5). Since the data for both periods are not comparable, we estimated the model separately for each period and also for the whole period. The results shown in Table A.5 indicate that war zones are associated with higher transport costs, especially in the second period ( 2 percent increase in trade costs when the route includes 1 additional war zone). The results are robust to adding aggregate attacks (see last column, Table A.5). This fact could be indicating that non-piracy related war zones are possibly also influencing transport prices. It is indeed likely that warzones directly influence costs -and especially insurance costs- regardless of piracy. The single correlation coefficients between warzone and aggregate attacks and the number of hijacks is 0.28 and 0.41 , respectively.

Finally, although our model cannot directly test the impact of the operation Atalanta ${ }^{13}$, we try to infer whether the operation could help to decrease transport costs by comparing the number of piracy incidents before and after the intervention. Patrol missions began in 2008 and an international maritime corridor protected by war ships (Internationally Recommended Transit Corridor or IRTC) was introduced in 2009 (Figure A.3). Figure A.4 presents the data for maritime piracy incidents (total and hijacked ships in the Red Sea and Gulf of Aden Region)

\footnotetext{
${ }^{12}$ We would like to thank an anonymous referee for this suggestion.

${ }^{13}$ Our transport cost data are only available for the period (1999-2007), whereas the operation Atlanta started in 2008.
} 
between 2001 and 2009. The beginning of the military operations in the region is indicated with a vertical red line. The figure shows that the number of hijacking acts has not decreased since operations began and the number of aggregate attacks linked to Somali piracy has increased considerably. These numbers reflect the changing strategy of the Somali pirates in response to the increasing military presence in the region. Pirates seem less successful in their attempts, probably due to the measures taken. As a consequence, to capture the same numbers of ships, pirates have increased their zone of action and the number of attacks. The naval presence has certainly increased the cost for Somali pirates by increasing the number of operations needed to seize a vessel, but it remains uncertain whether it has succeeded in decreasing maritime transport costs in the region. This last question requires further investigation.

\section{CONCLUSIONS}

In this paper we quantify the impact of modern maritime piracy on the maritime transport cost of trade between European Union and Asian countries. The main results indicate that the effect is substantial and significant. Piracy increases maritime trade costs between Europe and Asia by a non negligible amount.

The presence of failed or weak states along the main maritime trade route between Europe and Asia selectively harms trade between the two continents. In a context where it has been demonstrated that a small downward variation in trade barriers could allow the entrance of smaller firms into international markets (Melitz, 2003; Chaney, 2008), the disadvantage of higher transport costs between Europe and Asia harms European interests in comparison to its competitors' in the expanding markets of Asia. 
In addition, the increase in transport costs due to maritime piracy could lead to some shipping companies exploiting the Arctic route between Europe and Asia passing by the coasts of Russia. The route has been free of ice for at least three years from the end of August to the beginning of October. Without the cost of employing ice breaker ships to escort commercial vessels, the route has been demonstrated to be more economical than the Suez route (Xu et al. 2011). Adding the price of maritime piracy to the Suez route makes the northern route an interesting and safe alternative, at least for a few months.

Until now, the various military operations put in place in the Gulf of Aden and in particular the operation Atalanta of the European Union have not succeeded to curb down the occurrence of piracy incidents, but it has forced the pirates to extend their range of action. It is only by reducing significantly the number of hijacking that the European navies could transfer the supplementary cost to ship merchandizes from private shipping companies and consumers to national governments and taxpayers. Future research should be directed towards determining the loss of welfare and the markets distortions associated with each of these two options. 


\section{REFERENCES}

Anderson, J. E., and Marcouiller, D., (2002) Insecurity and the pattern of trade: an empirical investigation. Review of Economics and Statistics 84, 345-52.

Anderson, J. E., and Marcouiller, D., (2005) Anarchy and Autarky: Endogenous Predation as a Barrier to Trade. International Economic Review 46, 189-214.

Bendall, H.B., (2010) Cost of Piracy: A Comparative Voyage Approach. Maritime Economics and Logistics 12, 178-195.

Bensassi, S. and Martínez-Zarzoso, I. (2011) How Costly is Modern Maritime Piracy for the International Community?., Review of International Economics, forthcoming.

Coe, D. T., Subramanian, A. and Tamirisa, N. T. (2002) The Missing Globalization Puzzle, International Monetary Fund Working Paper (WP/02/171).

Baier, S. L. and Bergstrand, J. H. (2001) The Growth of World Trade: Tariffs, Transport Costs, and Income Similarity. Journal of International Economics 53, 1-27.

Fu, X., Ng A. K.Y., Lau Y., (2010) The Impacts of Maritime Piracy on Global Economic Development: the Case of Somalia. Maritime Policiy \& Management, 37(7), 677-698

Hastings, J. V., (2009) Geographies of State Failure and Sophistication in Maritime Piracy Hijackings. Political Geography, 28(4), 213-223.

Hummels, D. (1999a) Towards A Geography of Trade Costs. University of Chicago. Mimeographed document, Chicago.

Hummels, D. (1999b) Have International Transportation Costs Declined? University of Chicago. Mimeographed document, Chicago.

Jonkeren, O., Demirel, E., van Ommeren, J. and Rietveld, P. (2011) Endogenous transport prices and trade imbalances. Journal of Economic Geography, forthcoming.

Kiourktsoglou, G., Coutroubis A. D., (2010) Somali Piracy vs Flag of Attacked Vessel. Working Paper. University of Greenwich, London.

Korinek, J. (2008) Clarifying Trade Costs in Maritime Transport. OECD Working Paper TAD/TC/WP(2008)10, Paris.

Korinek, J. and Sourdin, P. (2009a) Clarifying Trade Costs: Maritime Transport and its Effect on Agricultural Trade. OECD trade Policy Working Paper 92, Paris.

Korinek, J. and Sourdin, P. (2009b) Maritime Transport Costs and their Impact on Trade. OECD TAD/TC/WP(2009)7, Paris.

Limao, N. and Venables, A. J. (2001) 'Infrastructure, Geographical Disadvantage and Transport Costs' World Bank Economic Review, 15 (3), 451-479. 
Martínez-Zarzoso, I. and Suárez-Burguet, C. (2005) Transport costs and trade: Empirical evidence for Latin American imports from the European Union. Journal of International Trade \& Economic Development, 14(3), 353-371.

Mejia, M., Cariou, P., Wolff, F., (2009) Is Maritime Piracy Random? Applied Economics Letters, 16, 891-895.

Micco, A., Pérez, N. (2001) Maritime Transport Costs and Port Efficiency. Inter-American Development Bank, Research Working Paper, Washington.

Mirza, D., Verdier, T., (2008) International Trade, Security and Transnational Terrorism: Theory and a Survey of Empirics. Journal of Comparative Economics, 36, 179-194.

Murphy, N. (2008) Piracy and the exploitation of sanctuary. In J. H. Norwitz (Ed.), Armed groups: Studies in national security, counterterrorism and counterinsurgency. Newport, RI: U.S. Naval War College.

Oguledo, V.I. and Mcphee, C.R. (1994) Gravity models: a reformulation and an application to discriminatory trade arrangements. Applied Economics, 26, 107-120.

Ong-Webb, G. G. (2007) Piracy in maritime Asia: current trends. In P. Lehr (Ed.),Violence at sea: Piracy in the age of global terrorism. New York: Routledge.

Ploch, L., Blanchard, C. M., O’Rourke, R., Mason R. C., and King, R.O. (2010). Piracy off the Horn of Africa. Congressional Research Service R405528, April 27, 2010.

Radelet, S., Sachs, J. (1998) Shipping Costs, Manufactured Exports and Economic Growth. Harvard University, Harvard Institute for International Development. Mimeographed document. Harvard, MA, USA.

Sánchez, R. J., Hoffmann, J., Micco, A., Pizzolitto G. and Sgut, M. (2002) Port Efficiency and International Trade, Conference Proceedings, IAME Annual Meeting and Conference, Panama, November .

Wilmsmeier, G., Martínez-Zarzoso, I., (2010). Determinants of Maritime Transport Costs: A Panel Data Analysis. Transportation Planning and Technology 33, 117-136.

Xu, H., Yin, Z., Jia, D., Jin, F, and Ouyang, H. (2011) The potential seasonal alternative of Asia-Europe container service via Northern sea route under the Arctic sea ice retreat. Maritime Policy \& Management, Vol. 38, Iss. 5. 
Figure 1: Maritime regions

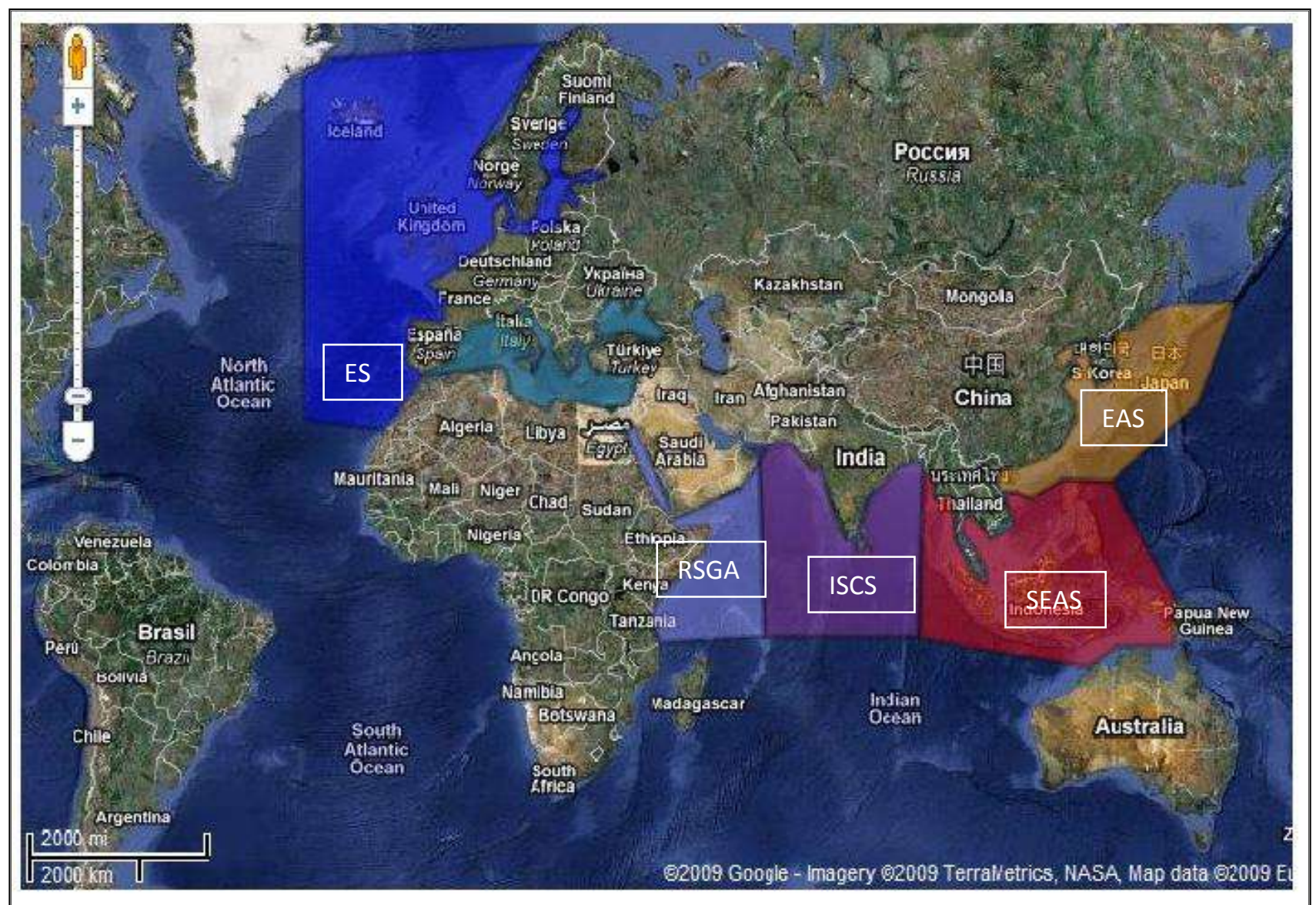

Source: own elaboration using data from IMB Piracy Reporting Center, International Maritime Bureau, ICC Commercial Crime Services, London, UK. http://www.icc-ccs.org 
Figure 2: Average transport freight rates for two alternative routes

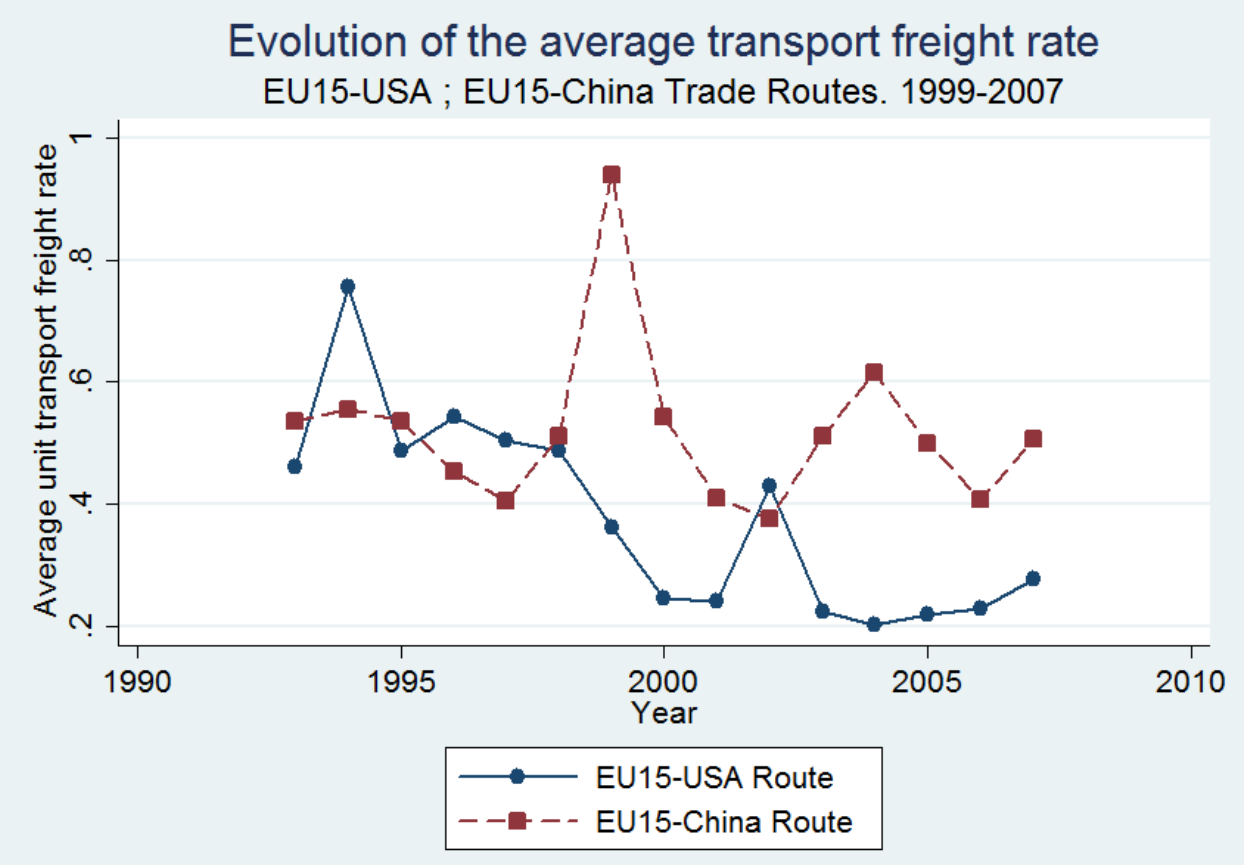

Source: own elaboration.

Figure 3: Number of Piracy Incidents on the Europe-East Asia Trade Route

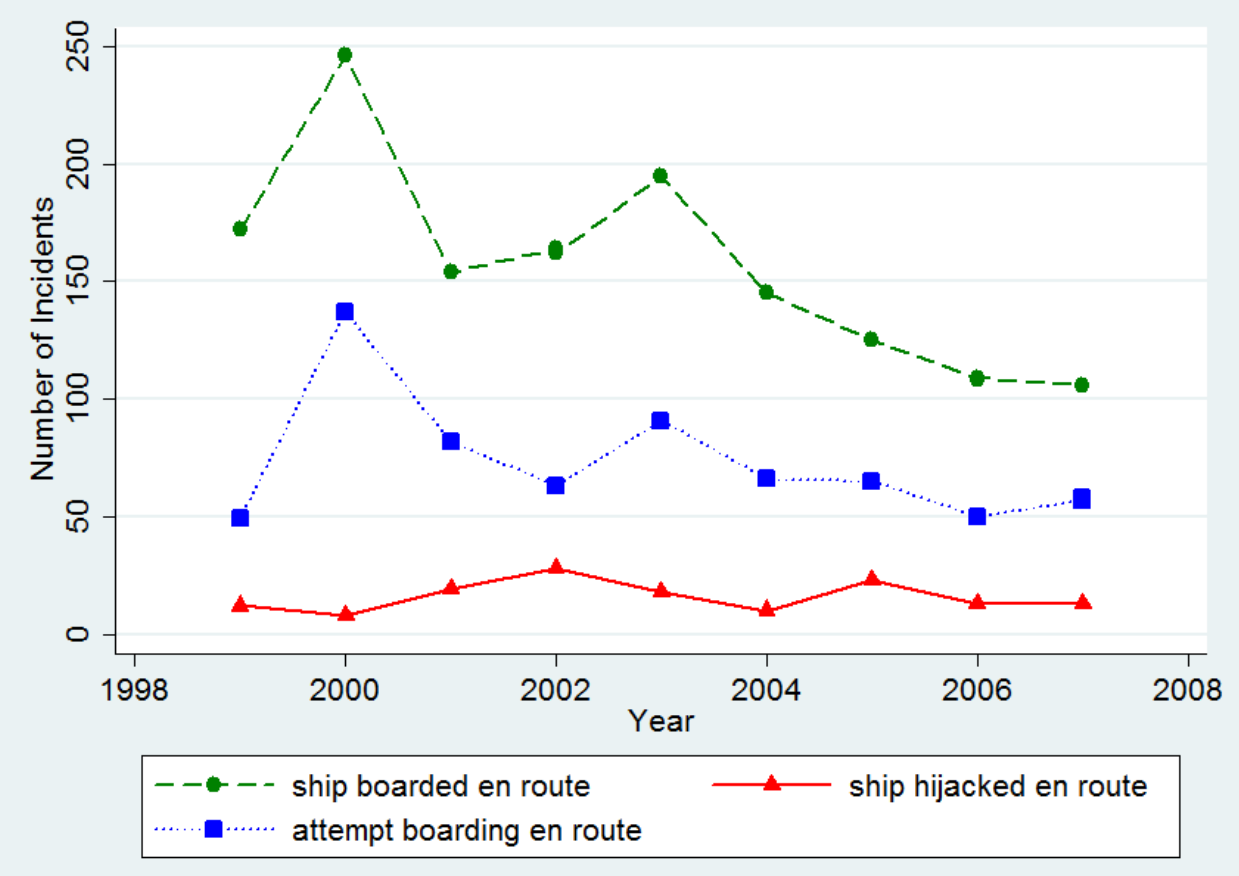


Source: own elaboration.

Figure 4: Average Maritime unit transport costs for 4 types of goods (EU to Asia, dollars)

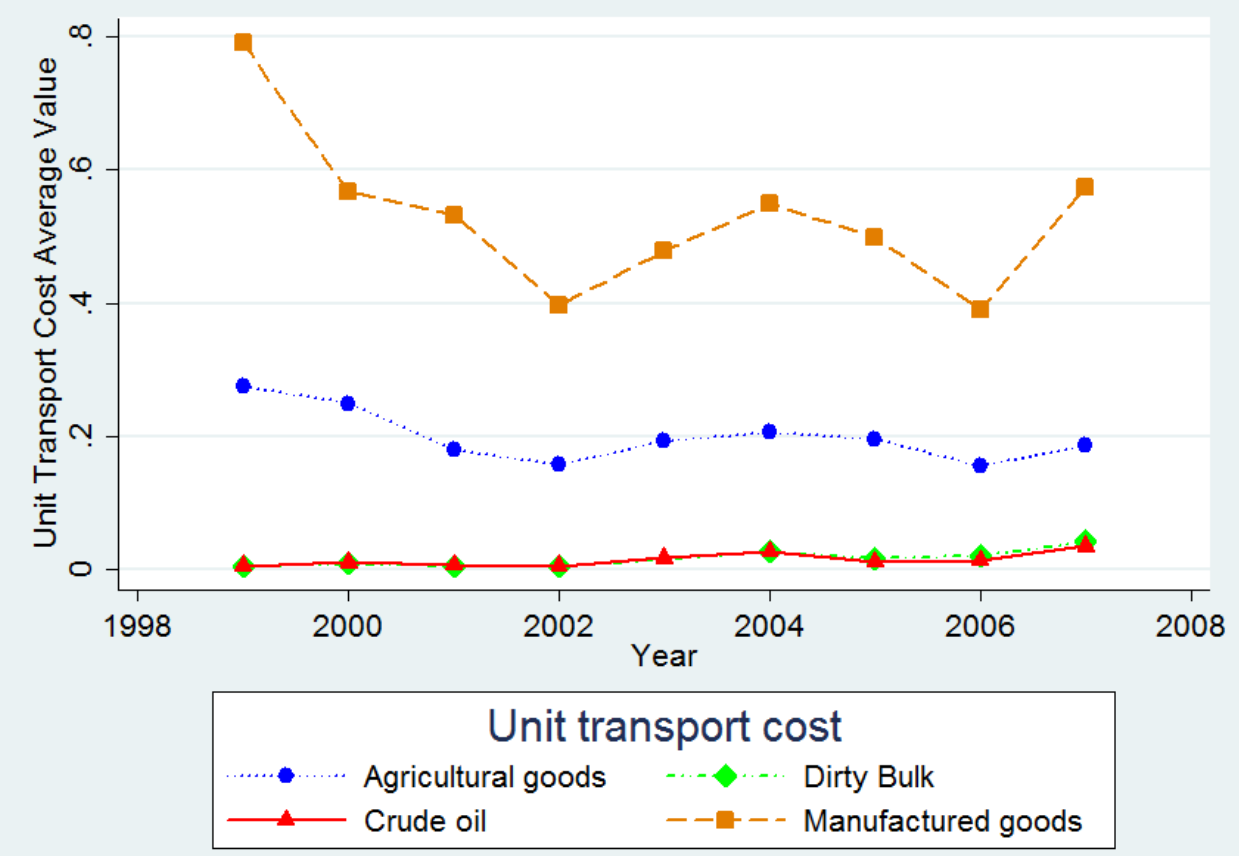

Source: own elaboration. 
Table 1: Summary Statistics

\begin{tabular}{|c|c|c|c|c|c|}
\hline Variable & Obs. & Mean & Std. Dev. & Min. & Max. \\
\hline $\mathrm{TC}$ & 16152 & 0.3415101 & 1.014443 & 0 & 49.9656 \\
\hline $\operatorname{Ln} Y_{i}$ & 16152 & 27.8959 & 2.241851 & 22.01682 & 30.38747 \\
\hline $\operatorname{Ln} Y_{j}$ & 16152 & 28.17277 & 1.926653 & 24.21019 & 30.38747 \\
\hline Ln Pop $_{i}$ & 16152 & 18.59602 & 1.689092 & 12.86876 & 20.99929 \\
\hline $\mathrm{Ln} \mathrm{Pop}_{\mathrm{j}}$ & 16152 & 18.6692 & 1.507516 & 15.19143 & 20.99929 \\
\hline t_hijack & 16152 & 14.34243 & 6.613979 & 1 & 28 \\
\hline t_boarded & 16152 & 135.6421 & 52.09402 & 34 & 246 \\
\hline t_attempt & 16152 & 64.45369 & 27.446 & 12 & 137 \\
\hline $\operatorname{Ln} \operatorname{Imb}_{\mathrm{ij}}$ & 15759 & 16.7 & 1.993194 & 7.149917 & 19.9472 \\
\hline $\operatorname{Ln} X M_{i j}$ & 15818 & 17.74937 & 1.90722 & 4.85203 & 20.54754 \\
\hline War Zone & 14477 & 16.05754 & 4.451584 & 6 & 21 \\
\hline
\end{tabular}

TC denotes unitary maritime transport cost. 
Table 2: The effect of piracy on transport costs. Baseline Results

\begin{tabular}{|c|c|c|c|c|c|c|c|}
\hline LSDV & All goods & Manuf. & Agric. & Raw Mat. & Crude Oil & All goods & All goods \\
\hline \multirow[t]{2}{*}{ t_hijack } & $0.009 * *$ & $0.007 *$ & $0.010 *$ & -0.011 & -0.042 & & \\
\hline & 2.213 & 1.714 & 1.862 & -0.778 & -1.377 & & \\
\hline \multirow[t]{2}{*}{ t_boarded } & $0.004 * * *$ & $0.003 * * *$ & $0.006 * * *$ & $0.016^{* *}$ & $0.017^{* *}$ & & \\
\hline & 8.218 & 2.87 & 5.959 & 2.36 & 2.472 & & \\
\hline \multirow[t]{2}{*}{ t_total } & & & & & & $0.003 * * *$ & \\
\hline & & & & & & 8.675 & \\
\hline \multirow[t]{2}{*}{ Success_rate } & & & & & & & $2.012 * * *$ \\
\hline & & & & & & & 3.333 \\
\hline \multirow[t]{2}{*}{$\operatorname{Ln} Y_{i}$} & -0.025 & -0.014 & -0.081 & 1.124 & $1.094 *$ & -0.004 & 0.071 \\
\hline & -0.456 & -0.168 & -1.269 & 1.157 & 2.06 & -0.076 & 1.07 \\
\hline \multirow[t]{2}{*}{$\operatorname{Ln} Y_{j}$} & $0.170 * * *$ & $0.191 * * *$ & 0.117 & $2.344 * * *$ & $1.895 * *$ & $0.202 * * *$ & $0.215^{* * *}$ \\
\hline & 2.922 & 2.785 & 1.247 & 5.613 & 2.598 & 3.281 & 2.873 \\
\hline \multirow[t]{2}{*}{ Ln Pop ${ }_{i}$} & -0.428 & -0.264 & -0.001 & $-17.843 * *$ & $-14.560 *$ & -0.587 & $-1.120^{*}$ \\
\hline & -0.98 & -0.396 & -0.002 & -2.857 & -1.947 & -1.285 & -1.986 \\
\hline \multirow[t]{2}{*}{ Ln Popi } & -0.241 & -0.176 & 0.791 & $-55.363 * * *$ & $-53.822 * * *$ & -0.223 & 0.101 \\
\hline & -0.372 & -0.21 & 1.393 & -5.821 & -5.346 & -0.348 & 0.135 \\
\hline \multirow[t]{2}{*}{$\operatorname{Ln} \operatorname{Imb}_{\mathrm{ij}}$} & -0.004 & 0.002 & -0.003 & $-0.349^{*}$ & -0.133 & -0.004 & -0.007 \\
\hline & -0.411 & 0.141 & -0.244 & -1.925 & -0.592 & -0.416 & -0.704 \\
\hline \multirow[t]{2}{*}{$\operatorname{Ln} X M_{i j, t-1}$} & -0.028 & $-0.087 * *$ & 0.025 & 0.244 & -0.176 & -0.031 & $-0.045^{*}$ \\
\hline & -1.379 & -2.269 & 0.966 & 1.156 & -0.337 & -1.358 & -1.774 \\
\hline $\mathrm{R}^{2}$ _adjusted & 0.697 & 0.685 & 0.573 & 0.696 & 0.784 & 0.696 & 0.696 \\
\hline Nobs & 15758 & 11319 & 4244 & 110 & 85 & 15758 & 15758 \\
\hline RMSE & 0.4984662 & 0.5018692 & 0.4471734 & 0.6136655 & 0.5840678 & 0.4987232 & 0.4994913 \\
\hline LL & -11314.76 & -8198.159 & -2569.04 & -83.46222 & -57.91903 & -11323.39 & -11347.64 \\
\hline
\end{tabular}

Note: t-statistics are calculated using robust standard errors clustered by country pair. Ln expresses natural logarithms. All regressions are with time, sector 2-digit and trading-pair fixed effects. ***, **, *, indicate significance at $1 \%, 5 \%$ and $10 \%$, respectively. 
Table 3: Results with piracy variables and trade volumes lagged

\begin{tabular}{|c|c|c|c|c|c|}
\hline LSDV & All goods & Manuf. & Agric. & Raw Mat. & Crude Oil \\
\hline \multirow[t]{2}{*}{ t_hijack (t-2) } & $0.016 * * *$ & $0.015^{* * *}$ & $0.014 * * *$ & $0.078 * * *$ & $0.063 * *$ \\
\hline & 7.241 & 4.797 & 5.054 & 3.41 & 3.073 \\
\hline \multirow[t]{2}{*}{ t_boarded (t-2) } & $0.004 * * *$ & $0.004 * * *$ & $0.005 * * *$ & -0.008 & -0.005 \\
\hline & 4.111 & 2.906 & 5.713 & -0.744 & -0.995 \\
\hline \multirow[t]{2}{*}{$\operatorname{Ln} Y_{i}$} & -0.081 & -0.105 & -0.071 & -0.501 & $1.472 * * *$ \\
\hline & -1.008 & -1.176 & -0.603 & -0.213 & 4.229 \\
\hline \multirow[t]{2}{*}{$\operatorname{Ln} Y_{j}$} & $0.372 * * *$ & $0.369 * * *$ & $0.319 * *$ & $2.089 *$ & $2.074 * * *$ \\
\hline & 3.817 & 4.017 & 2.236 & 2.215 & 5.624 \\
\hline \multirow[t]{2}{*}{ Ln $\mathrm{Pop}_{\mathrm{i}}$} & -0.024 & 0.696 & -1.347 & -33.833 & -7.557 \\
\hline & -0.039 & 0.918 & -1.318 & -1.553 & -1.607 \\
\hline \multirow[t]{2}{*}{ Ln $\mathrm{Pop}_{\mathrm{i}}$} & -0.253 & -0.539 & 1.349 & $-48.164 * *$ & $-38.839 * * *$ \\
\hline & -0.375 & -0.705 & 1.313 & -2.509 & -6.184 \\
\hline \multirow[t]{2}{*}{$\operatorname{Ln} \operatorname{Imb}_{\mathrm{ij}}$} & -0.02 & -0.017 & -0.007 & -0.269 & $-0.293 * * *$ \\
\hline & -1.536 & -1.284 & -0.359 & -1.465 & -3.292 \\
\hline \multirow[t]{2}{*}{$\operatorname{Ln} \mathrm{XM}_{\mathrm{ij}, \mathrm{t}-1}$} & 0.004 & -0.047 & 0.01 & 0.167 & -0.094 \\
\hline & 0.107 & -0.853 & 0.286 & 0.828 & -0.644 \\
\hline $\mathrm{R}^{2}$ _adjusted & 0.741 & 0.734 & 0.601 & 0.636 & 0.812 \\
\hline Nobs & 10847 & 7831 & 2899 & 60 & 57 \\
\hline RMSE & 0.4396452 & 0.4414019 & 0.3954396 & 0.6187129 & 0.5100989 \\
\hline LL & -6406.845 & -4651.623 & -1390.041 & -38.39437 & -26.05642 \\
\hline
\end{tabular}

Note: t-statistics are calculated using robust standard errors clustered by country pair. Ln expresses natural logarithms. All regressions are with time, sector 2-digit and trading-pair fixed effects. ***, **, *, indicate significance at $1 \%, 5 \%$ and $10 \%$, respectively. 
Table 4: Results for Containerized trade and for Tankers and dirty bulk

\begin{tabular}{|c|c|c|c|c|}
\hline \multirow{2}{*}{ LSDV } & \multicolumn{2}{|r|}{2 lags } & \multicolumn{2}{|r|}{1 lag } \\
\hline & Containers & DirtyBulk+tankers & Containers & DirtyBulk+tankers \\
\hline \multirow{2}{*}{ t_hijack $(\mathrm{t}-2) /(\mathrm{t}-1)$} & $0.013 * * *$ & $0.060 * * *$ & $0.014 * * *$ & $0.021 * *$ \\
\hline & 7.811 & 9.423 & 6.666 & 2.237 \\
\hline \multirow[t]{2}{*}{ t_boarded $(t-2) /(t-1)$} & $0.005 * * *$ & -0.005 & $0.004 * * *$ & -0.005 \\
\hline & 4.687 & -0.934 & 4.676 & -1.685 \\
\hline \multirow[t]{2}{*}{$\operatorname{Ln} Y_{i}$} & $-0.126^{*}$ & $0.700 * *$ & -0.049 & 0.596 \\
\hline & -1.698 & 2.141 & -0.758 & 1.671 \\
\hline \multirow[t]{2}{*}{$\operatorname{Ln} Y_{j}$} & $0.347 * * *$ & $1.471 * * *$ & $0.127^{* *}$ & 0.022 \\
\hline & 3.622 & 3.158 & 2.543 & 0.041 \\
\hline \multirow[t]{2}{*}{ Ln $\mathrm{Pop}_{\mathrm{i}}$} & 0.463 & -4.672 & -0.103 & -3.764 \\
\hline & 0.745 & -0.913 & -0.253 & -0.837 \\
\hline \multirow[t]{2}{*}{ Ln Popi } & -0.287 & $-37.920 * * *$ & 0.307 & $-22.894 * *$ \\
\hline & -0.448 & -5.452 & 0.535 & -2.862 \\
\hline \multirow[t]{2}{*}{$\operatorname{Ln} \operatorname{Imb}_{\mathrm{ij}}$} & -0.01 & $-0.218 * *$ & -0.009 & -0.103 \\
\hline & -0.803 & -2.706 & -0.589 & -1.439 \\
\hline \multirow[t]{2}{*}{$\operatorname{Ln} X_{\mathrm{ij}, \mathrm{t}-1}$} & -0.028 & 0.095 & 0.021 & 0.031 \\
\hline & -0.602 & 0.72 & 0.553 & 0.181 \\
\hline $\mathrm{R}^{2} \_$adjusted & 0.732 & 0.738 & 0.728 & 0.681 \\
\hline Nobs & 10972 & 205 & 12735 & 243 \\
\hline RMSE & 0.4407706 & 0.5555792 & 0.4460124 & 0.60134 \\
\hline LL & -6514.1 & -149.9926 & -7720.481 & -200.5523 \\
\hline
\end{tabular}

Note: t-statistics are calculated using robust standard errors clustered by country pair. Ln expresses natural logarithms. All regressions are with time, sector 2-digit and trading-pair fixed effects. Columns 1 and 2 (3 and 4) present the results when the second lag (first lag) of the piracy variables are used. ***,**, *, indicate significance at $1 \%, 5 \%$ and $10 \%$, respectively. 
Table 5: Generalized Method of Moments estimation results

\begin{tabular}{|c|c|c|c|}
\hline GMM & All goods & Manuf. & Agric. \\
\hline \multirow[t]{2}{*}{ t_hijack } & $0.011 * * *$ & 0.009 & $0.014 * * *$ \\
\hline & 2.858 & 1.503 & 3.108 \\
\hline \multirow[t]{2}{*}{ t_attempt } & $0.006 * * *$ & $0.005^{* *}$ & $0.007 * * *$ \\
\hline & 4.255 & 2.197 & 3.915 \\
\hline \multirow[t]{2}{*}{$\operatorname{Ln} Y_{i}$} & $-0.276^{* * *}$ & $-0.301 * * *$ & $-0.306 * *$ \\
\hline & -3.454 & -3.141 & -2.127 \\
\hline \multirow[t]{2}{*}{$\operatorname{Ln} Y_{j}$} & $0.325 * * *$ & $0.380 * * *$ & 0.141 \\
\hline & 3.913 & 3.912 & 0.942 \\
\hline \multirow[t]{2}{*}{ Ln $\mathrm{Pop}_{\mathrm{i}}$} & 0.052 & 0.884 & $-1.508^{*}$ \\
\hline & 0.105 & 1.49 & -1.709 \\
\hline \multirow[t]{2}{*}{ Ln Pop $_{i}$} & $-1.624 * * *$ & $-1.908 * * *$ & 0.008 \\
\hline & -3.167 & -3.044 & 0.011 \\
\hline \multirow[t]{2}{*}{$\operatorname{Ln} \operatorname{Imb}_{\mathrm{ij}}$} & 0.001 & 0.005 & 0.003 \\
\hline & 0.073 & 0.291 & 0.126 \\
\hline \multirow[t]{2}{*}{$\operatorname{Ln} \mathrm{XM}_{\mathrm{ij}, \mathrm{t}-1}$} & -0.021 & -0.071 & 0.013 \\
\hline & -0.606 & -1.412 & 0.267 \\
\hline $\mathrm{R}^{2}$ & 0.75 & 0.744 & 0.619 \\
\hline Nobs & 9028 & 6522 & 2415 \\
\hline Hansen & 8.729 & 4.212 & 5.05 \\
\hline (prob) & 0.071 & 0.378 & 0.28 \\
\hline
\end{tabular}

Note: t-statistics are calculated using robust standard errors clustered by country pair. Ln expresses natural logarithms. All regressions are with time, sector 2-digit and trading-pair fixed effects. ***, **, *, indicate significance at $1 \%, 5 \%$ and $10 \%$, respectively. 


\section{Appendix}

Table A.1: Maritime Region Navigated according to each trade route

\begin{tabular}{|c|c|c|c|c|c|}
\hline \multirow[t]{2}{*}{ Maritime Route } & \multicolumn{5}{|c|}{ Maritime regions navigated } \\
\hline & $\begin{array}{l}\text { European Seas } \\
\text { (ES) }\end{array}$ & $\begin{array}{c}\text { Red Sea/ Gulf } \\
\text { of Aden } \\
\text { (RGSA) }\end{array}$ & $\begin{array}{l}\text { Indian Sub } \\
\text { Continental } \\
\text { Seas (ISCS) }\end{array}$ & $\begin{array}{c}\text { South East } \\
\text { Asian Seas } \\
\text { (SEAS) }\end{array}$ & $\begin{array}{l}\text { East Asian } \\
\text { Seas (SEC) }\end{array}$ \\
\hline $\begin{array}{l}\text { Europe - Indian Sub } \\
\text { Continent }\end{array}$ & $\mathrm{X}$ & $\mathrm{X}$ & $\mathrm{X}$ & & \\
\hline Europe - South East Asia & $\mathrm{X}$ & $X$ & $X$ & $\mathrm{X}$ & \\
\hline Europe - East Asia & $\mathrm{X}$ & $\mathrm{X}$ & $X$ & $\mathrm{X}$ & $\mathrm{X}$ \\
\hline
\end{tabular}

Source: own elaboration.

Table A.2: Sources and variables

\begin{tabular}{|c|c|c|}
\hline Dependent Variables & Description & Source \\
\hline $\begin{array}{l}T C_{i j t}: \text { Unit Maritime Transport } \\
\text { Cost from i to } \mathrm{j} \text { in year } \mathrm{t}\end{array}$ & $\begin{array}{l}\text { Cost in } \$ \text { to transport one unit of } \\
\text { good from a country } \mathrm{i} \text { to a country } \mathrm{j} \\
\text { in year } \mathrm{t}\end{array}$ & OECD \\
\hline Independent Variables & Description & Source \\
\hline$Y_{i t}:$ Exporter's income & Exporter GDP, PPP (current \$) & WDI \\
\hline$Y_{j t}:$ Importer's income & Importer GDP, PPP (current \$) & WDI \\
\hline t_boarded & $\begin{array}{l}\text { number of ships boarded by pirates } \\
\text { on a particular route and year }\end{array}$ & IMB \\
\hline t_hijack & $\begin{array}{l}\text { number of ships hijacked by pirates } \\
\text { on a particular route }\end{array}$ & IMB \\
\hline t_attempt & $\begin{array}{l}\text { number of attempted acts of piracy } \\
\text { on a particular route }\end{array}$ & IMB \\
\hline$I m b_{i j t}$ & $\begin{array}{l}\text { Trade imbalance between country } i \\
\text { and country } j\end{array}$ & WDI \\
\hline$X M_{i j t}$ & $\begin{array}{l}\text { Trade volumes between countries } i \\
\text { and } j \text { in year } t\end{array}$ & Eurostat \\
\hline
\end{tabular}


Table A.3: Maritime War Zones

\begin{tabular}{|c|c|c|c|c|c|c|}
\hline Listed Areas & $1 / 8 / 11$ & $3 / 3 / 11$ & $16 / 11 / 10$ & $2 / 8 / 10$ & $11 / 3 / 10$ & $25 / 11 / 09$ \\
\hline \multicolumn{7}{|l|}{ Africa } \\
\hline Benin & 1 & 0 & 0 & 0 & 0 & 0 \\
\hline Djibouti excluding transit & 1 & 1 & 1 & 1 & 1 & 1 \\
\hline Eritrea, but only South of $150 \mathrm{~N}$ & 1 & 1 & 1 & 1 & 0 & 0 \\
\hline Gulf of Guinea & 1 & 0 & 0 & 0 & 0 & 0 \\
\hline Ivory Coast & 1 & 1 & 1 & 1 & 1 & 1 \\
\hline Libya & 1 & 1 & 0 & 0 & 0 & 0 \\
\hline Nigeria & 1 & 1 & 1 & 1 & 1 & 1 \\
\hline Somalia & 1 & 1 & 1 & 1 & 1 & 1 \\
\hline $\begin{array}{l}\text { Indian Ocean / Arabian Sea / Gulf of Aden / Gulf of Oman } \\
\text { / Southern Red Sea }\end{array}$ & 1 & 1 & 1 & 1 & 1 & 1 \\
\hline \multicolumn{7}{|l|}{ Asia } \\
\hline Pakistan & 1 & 1 & 1 & 1 & 1 & 1 \\
\hline Sri Lanka & 0 & 0 & 0 & 0 & 1 & 1 \\
\hline Thailand, but only the area of the southern Gulf coast & 0 & 0 & 0 & 0 & 0 & 1 \\
\hline \multicolumn{7}{|l|}{ Eastern Europe } \\
\hline Georgia & 1 & 1 & 1 & 1 & 1 & 1 \\
\hline \multicolumn{7}{|l|}{ Indonesia } \\
\hline The port of Balikpapan (SE Borneo) & 1 & 1 & 1 & 1 & 1 & 1 \\
\hline Borneo, but only the north east coast & 1 & 1 & 1 & 1 & 1 & 1 \\
\hline The port of Jakarta & 1 & 1 & 1 & 1 & 1 & 1 \\
\hline Sumatra, but only the north eastern coast & 1 & 1 & 1 & 1 & 1 & 1 \\
\hline \multicolumn{7}{|l|}{ Middle East } \\
\hline Bahrain excluding transit & 1 & 1 & 1 & 1 & 1 & 1 \\
\hline Iran & 1 & 1 & 1 & 1 & 1 & 0 \\
\hline Iraq, including all Iraqi offshore oil terminals & 1 & 1 & 1 & 1 & 1 & 1 \\
\hline Israel & 1 & 1 & 1 & 1 & 1 & 1 \\
\hline Lebanon & 1 & 1 & 1 & 1 & 1 & 1 \\
\hline Qatar excluding transit & 1 & 1 & 1 & 1 & 1 & 1 \\
\hline Saudi Arabia excluding transit & 1 & 1 & 1 & 1 & 1 & 1 \\
\hline Yemen & 1 & 1 & 1 & 1 & 1 & 1 \\
\hline \multicolumn{7}{|l|}{ Philipinnes } \\
\hline Mindanao & 1 & 1 & 1 & 1 & 1 & 1 \\
\hline Sulu Archipelago & 1 & 1 & 1 & 1 & 1 & 1 \\
\hline \multicolumn{7}{|l|}{ South America } \\
\hline Venezuela & 1 & 1 & 1 & 1 & 1 & 1 \\
\hline
\end{tabular}

Source: Joint War Committee, Listed Areas (Hull War, Strikes, Terrorism and Related Perils), reports 2011, 2010, 2009 (www.lmalloyds.com and www.iua.co.uk.) 
Table A.4: Type of vessels attacked (\%)

\begin{tabular}{l|rrrrrr}
\hline Type of Vessels & 2003 & 2004 & 2005 & 2006 & 2007 & 2008 \\
\hline \hline Bulk Carrier & $25.62 \%$ & $22.19 \%$ & $29.35 \%$ & $23.85 \%$ & $12.17 \%$ & $16.38 \%$ \\
Container & $12.58 \%$ & $14.59 \%$ & $10.87 \%$ & $20.50 \%$ & $20.15 \%$ & $16.72 \%$ \\
General cargo & $16.40 \%$ & $11.55 \%$ & $16.67 \%$ & $12.55 \%$ & $13.69 \%$ & $12.97 \%$ \\
Refrigerated & $1.57 \%$ & $3.04 \%$ & $1.09 \%$ & $1.26 \%$ & $2.66 \%$ & $2.73 \%$ \\
Tanker Chem. / Product & $11.01 \%$ & $17.02 \%$ & $15.58 \%$ & $14.64 \%$ & $19.77 \%$ & $18.77 \%$ \\
Tanker Crude Oil & $9.44 \%$ & $5.17 \%$ & $7.97 \%$ & $3.77 \%$ & $9.51 \%$ & $10.24 \%$ \\
Tanker LPG & $3.15 \%$ & $3.95 \%$ & $1.81 \%$ & $1.67 \%$ & $1.90 \%$ & $2.05 \%$ \\
Trawler / Fishing & $6.29 \%$ & $5.47 \%$ & $2.54 \%$ & $7.53 \%$ & $6.08 \%$ & $3.07 \%$ \\
Tug & $4.27 \%$ & $7.29 \%$ & $4.71 \%$ & $3.77 \%$ & $2.66 \%$ & $5.46 \%$ \\
Yacht & $3.37 \%$ & $3.34 \%$ & $2.54 \%$ & $4.18 \%$ & $3.04 \%$ & $3.07 \%$ \\
Other & $6.29 \%$ & $6.38 \%$ & $6.88 \%$ & $6.28 \%$ & $8.37 \%$ & $8.53 \%$ \\
\hline Source: IMB & & & & & &
\end{tabular}

Source: IMB report 2008. 
Table A.5: Estimating the effect of Warzones on transport costs

\begin{tabular}{|c|c|c|c|c|}
\hline Time Period: & 2000-2004 & 2005-2007 & 2000-2007 & 2000-2007 \\
\hline Variables: & $\mathrm{b} / \mathrm{t}$ & $\mathrm{b} / \mathrm{t}$ & $\mathrm{b} / \mathrm{t}$ & $\mathrm{b} / \mathrm{t}$ \\
\hline \multirow[t]{2}{*}{ Warzone (1 lag) } & -0.003 & $0.026 * * *$ & $0.004 *$ & $0.005^{* *}$ \\
\hline & -1.388 & 3.158 & 1.75 & 2.646 \\
\hline \multirow[t]{2}{*}{ Attacks (1 lag) } & & & & $0.001 * * *$ \\
\hline & & & & 5.754 \\
\hline \multirow[t]{2}{*}{$\operatorname{Ln} Y_{i}$} & -0.123 & 0.241 & -0.007 & 0.046 \\
\hline & -1.195 & 1.193 & -0.095 & 0.646 \\
\hline \multirow{2}{*}{$\operatorname{Ln} Y_{j}$} & $0.729 * * *$ & 0.385 & $0.427 * * *$ & $0.500 * * *$ \\
\hline & 7.258 & 1.603 & 3.652 & 4.524 \\
\hline \multirow[t]{2}{*}{ Ln Pop } & 0.989 & -2.752 & $-1.928 * *$ & $-1.210 * *$ \\
\hline & 0.793 & -1.417 & -2.657 & -2.048 \\
\hline \multirow[t]{2}{*}{ Ln Pop } & $-3.715 * *$ & -0.461 & $-1.669^{*}$ & $-1.548^{*}$ \\
\hline & -2.47 & -0.219 & -1.906 & -2.004 \\
\hline \multirow[t]{2}{*}{ Ln tradeim } & -0.043 & $-0.073 * *$ & $-0.031 * *$ & $-0.035^{* * *}$ \\
\hline & -1.291 & -2.361 & -2.156 & -2.784 \\
\hline \multirow[t]{2}{*}{ Ln XM } & 0.007 & 0.151 & 0.001 & 0.01 \\
\hline & 0.12 & 1.004 & 0.022 & 0.19 \\
\hline \multirow[t]{2}{*}{ Constant } & 28.912 & 31.41 & $46.075^{* * *}$ & $29.203 * *$ \\
\hline & 0.889 & 0.796 & 2.886 & 2.069 \\
\hline $\mathrm{R}^{2} \_\mathrm{a}$ & 0.758 & 0.713 & 0.722 & 0.724 \\
\hline Nobs & 6379 & 5109 & 11488 & 11488 \\
\hline RMSE & 0.4217721 & 0.4756815 & 0.4592004 & 0.4576549 \\
\hline LL & -3477.788 & -3385.441 & -7292.117 & -7252.882 \\
\hline
\end{tabular}

Note: t-statistics are calculated using robust standard errors clustered by country pair. L expresses natural logarithms. All regressions are with time, sector 2-digit and trading-pair fixed effects. ***, **, *, indicate significance at $1 \%, 5 \%$ and $10 \%$, respectively. 
Figure A.1: Number of piracy incidents in each region between 1999 and 2007
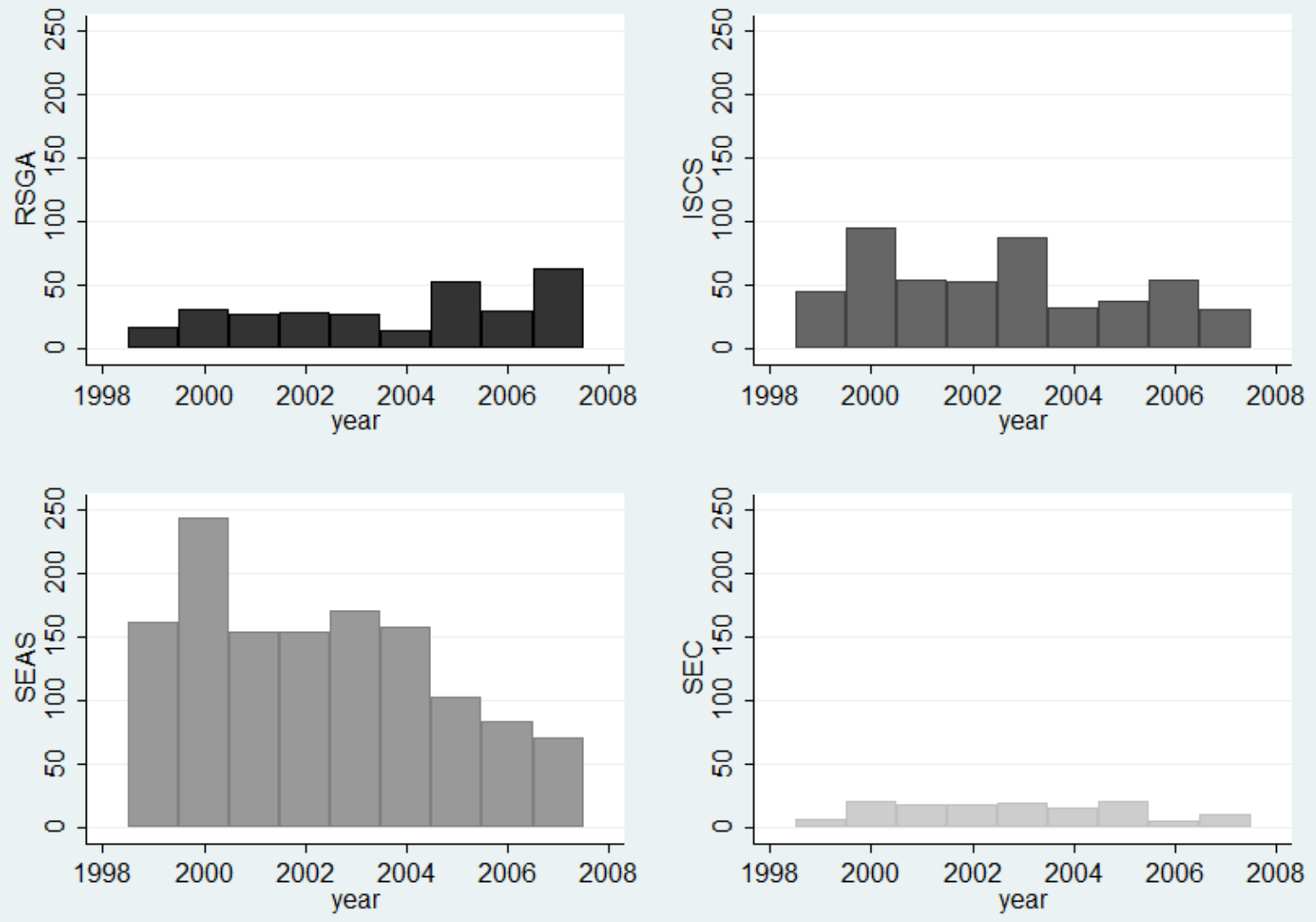

RGSA stands for Red Sea and Gulf of Aden, ISCS for Indian Sub Continent Seas, SEAS for South East Asia Seas and EAS for East Asia Seas. Source: own elaboration. 
Figure A.2: Number of incidents on three different routes linking Europe and Asia

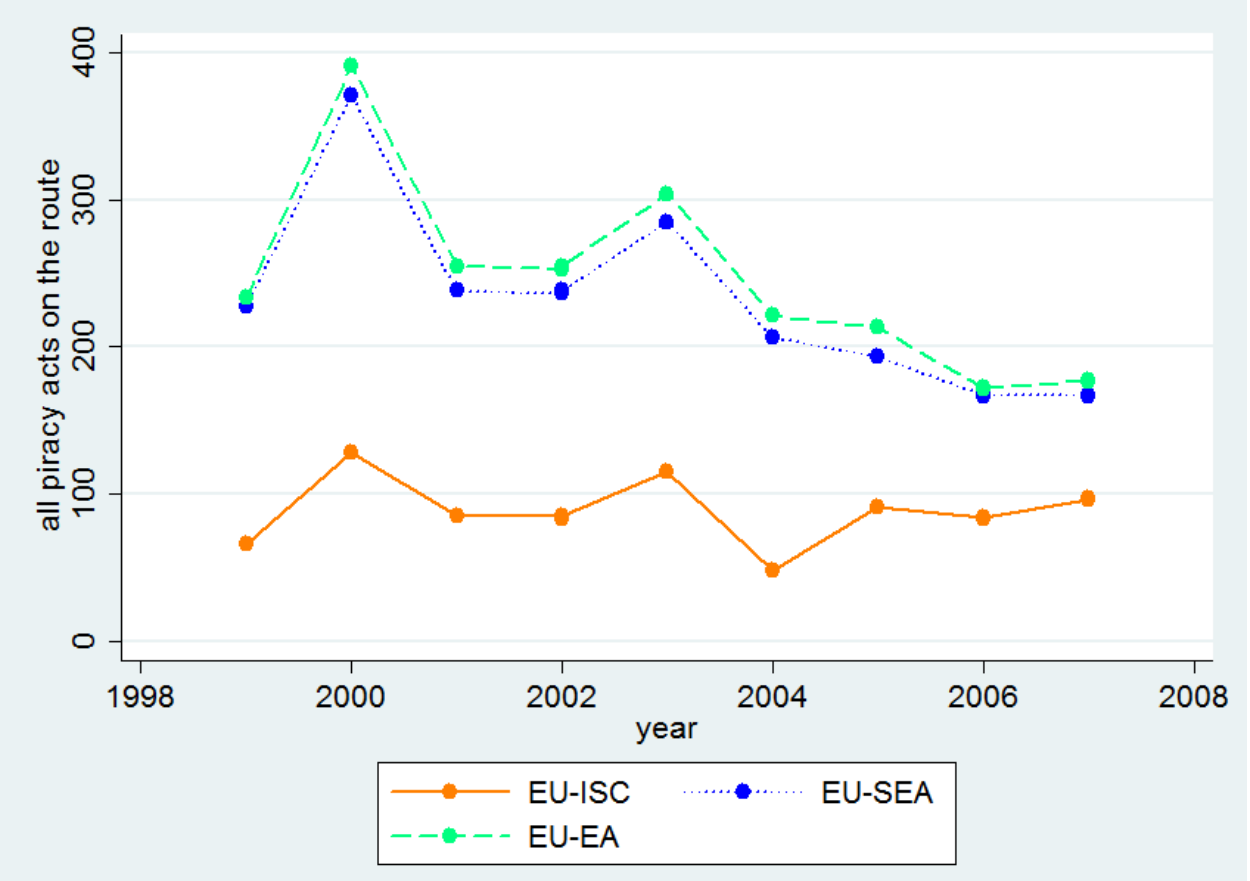

Source: own elaboration. The routes are: Indian Sub-Continental Seas (ISC), the South-East-Asian Seas (SEA) and the East-Asian Seas (EA). 
Figure A.3: Internationally Recommended Transit Corridor

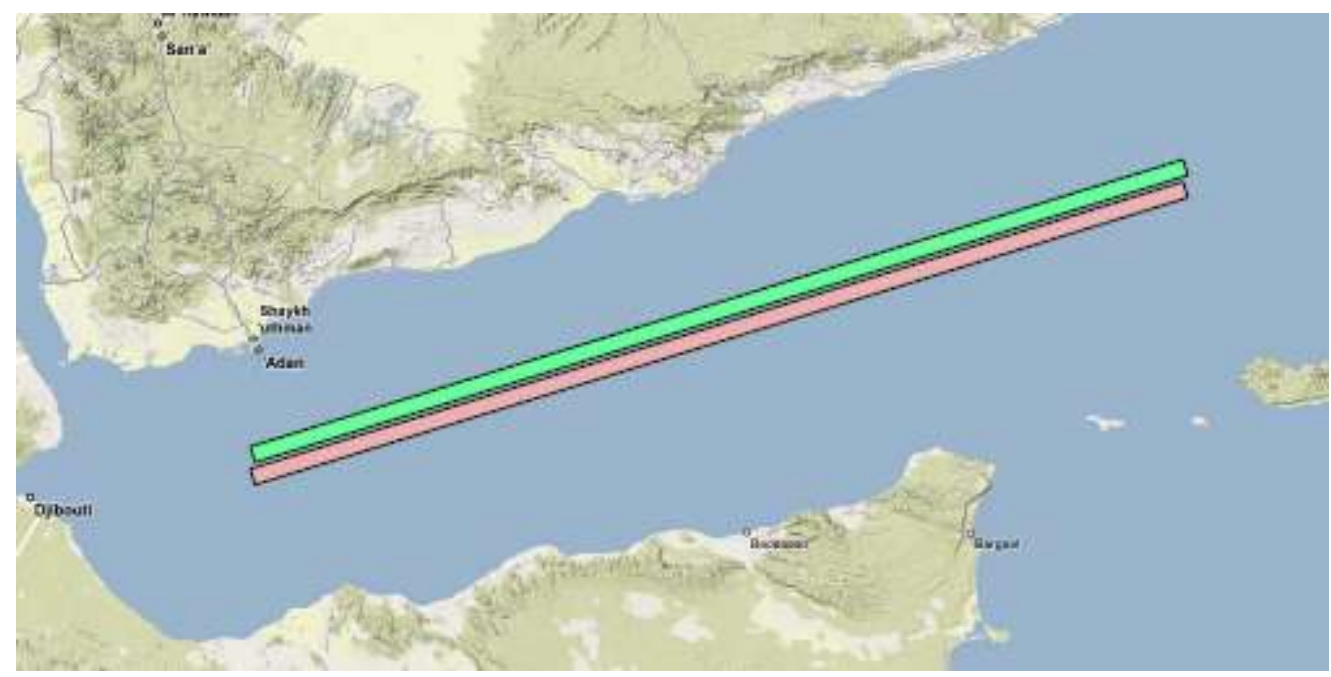

Figure A.4: Piracy acts in the Red Sea and Gulf of Aden Region from 2001 to 2010

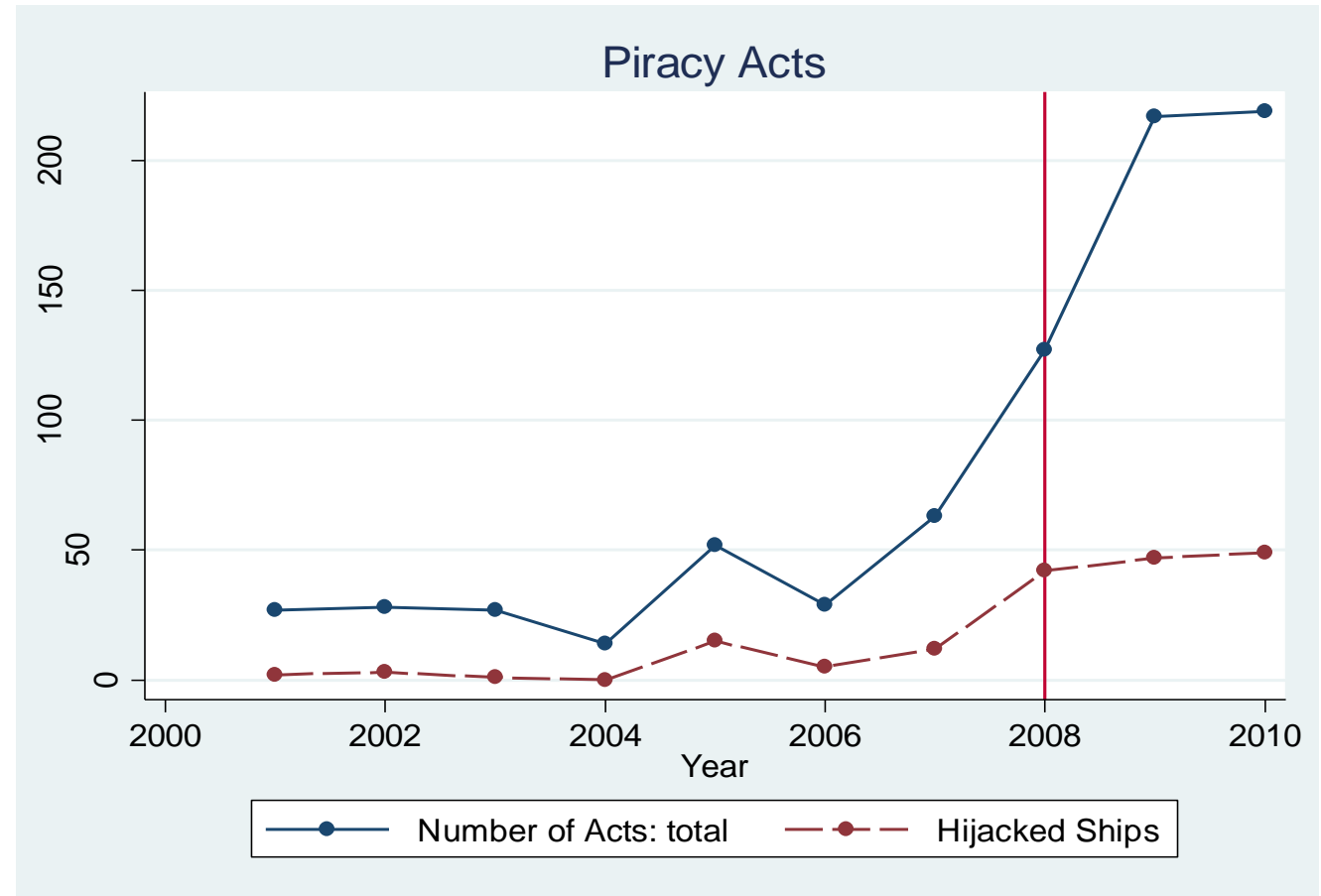

Source: International Maritime Bureau. 
Figure A.5: Number of Warzones on each trade route

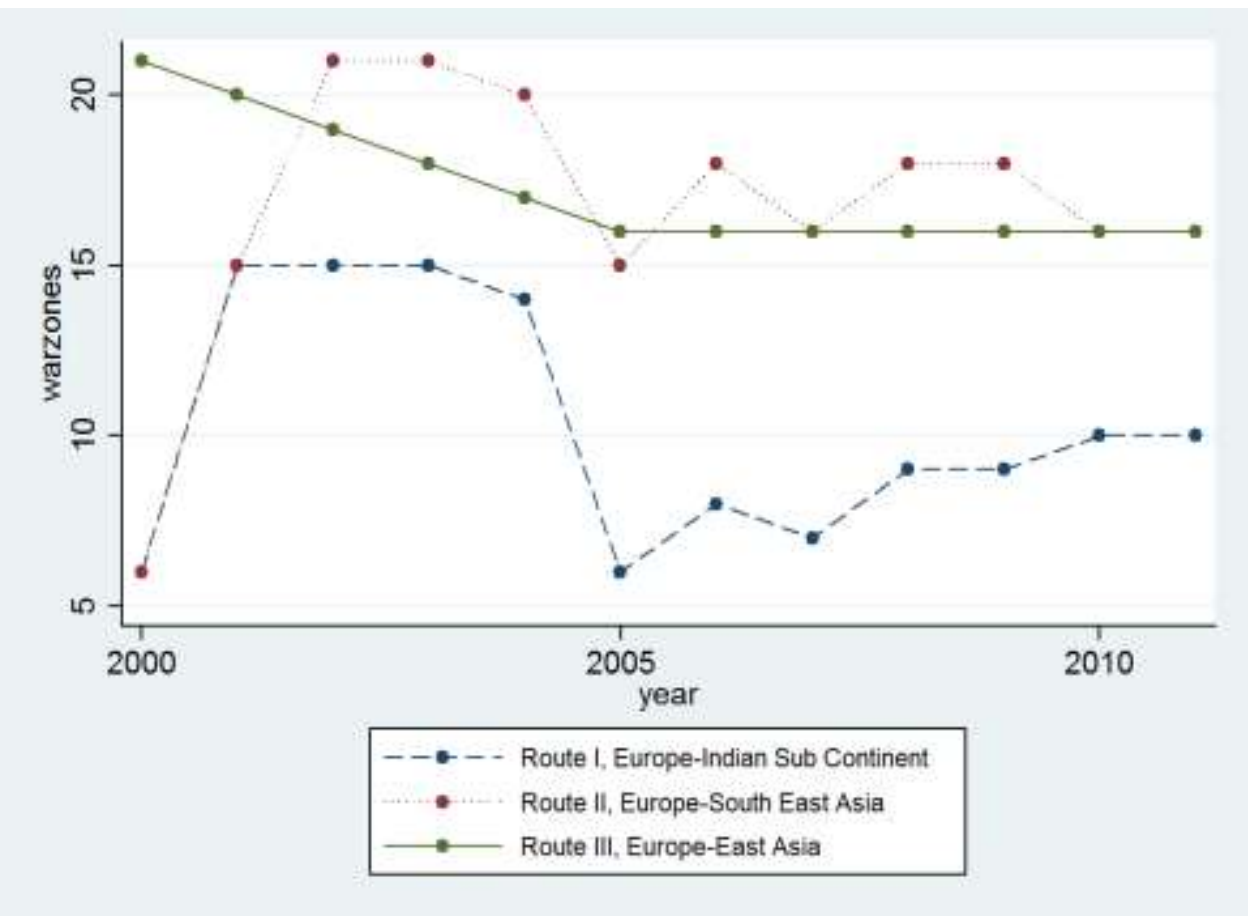

Source: Joint War Committee, Listed Areas (Hull War, Strikes, Terrorism and Related Perils), reports 2000-2011. 